\title{
Práva a povinnosti účastníka biomedicínskeho výskum s dôrazom na informovaný súhlas
}

\author{
Katarína Ševcová * \\ DOI: https://doi.org/10.24040/sap.2020.7.1.83-97
}

\begin{abstract}
Abstrakt:
ŠEVCOVÁ, Katarína: Práva a povinnosti účastníka biomedicinskeho výskum $s$ dôrazom na informovaný súhlas. Bioprávo je v podstate právna bioetika (vývoj tu prebieha od bioetiky smerom $\mathrm{k}$ právu) alebo, lepšie povedané, uplatňovanie zásad a praxe bioetiky $\mathrm{v}$ práve so sankciami, ktoré zákon predpokladá. A práve biomedicínsky výskum je oblast', kde je toto prepojenie dobre viditel'né. Vzhl'adom na dôležitost' hodnôt, ktoré sú vložené do lekárskeho výskumu, obvyklý informovaný súhlas typický pre každodenné lekárske postupy a starostlivost' sa nedá aplikovat' na experimentálne zásahy.
\end{abstract}

\section{Kl'účové slová:}

biomedicínsky výskum, etická komisia, informovaný súhlas, medicína, medicínske právo

\section{The Rights and Obligations of a Biomedical Research Participant with an Emphasis on Informed Consent}

\footnotetext{
Abstract:

ŠEVCOVÁ, Katarína: The Rights and Obligations of a Biomedical Research Participant With an Emphasis on Informed Consent. Biolaw is basically legal bioethics (the development here proceeds from bioethics towards the law) or, to put it more precisely, the application of the principles and practices of bioethics in the law with the sanctions envisaged by the law. It is biomedical research that is the area where this link is clearly visible. Given the importance of the values that are embedded in medical research, the usual informed consent typical of everyday medical procedures and care cannot be applied to experimental interventions.
}

Key words:

biomedical research, ethics committee, informed consent, medicine, medical law

Úvod

Medicína tak ako každá veda potrebuje výskum, aby mohla obmedzit' utrpenie chorých v budúcnosti a predchádzat' mu. Len tak sa zabezpečí rozvoj lekárskej vedy. Právne a etické otázky, ktoré vyvoláva, sú spojené hlavne s tým, že pri tomto postupe je práve potreba experimentovat' na l'udskej bytosti, a teda ohrozit' ju a jej práva. I

JUDr. Katarína Ševcová PhD. Univerzita Mateja Bela, Právnická fakulta, odborný asistent na

Katedre občianskeho a pracovného práva 
veda sa môže postavit' proti l'udskosti a je to práve zákonodarca, ktorý musí normalizovat' túto aktivitu a dat' jej jasný zmysel a orientáciu. Bioprávo je v podstate právna bioetika (vývoj tu prebieha od bioetiky smerom $\mathrm{k}$ právu) alebo, lepšie povedané, uplatňovanie zásad a praxe bioetiky v práve so sankciami, ktoré zákon predpokladá. A práve biomedicínsky výskum je oblast', kde je toto prepojenie dobre viditel'né.

Právnu definíciu klinického výskumu poskytuje ustanovenie $\$ 2$ ods. 12 zákona č. 576/ 2004 Z.z. o zdravotnej starostlivosti, službách súvisiacich s poskytovaním zdravotnej starostlivosti a o zmene a doplnení niektorých zákonov (d’alej len ZoZS). Biomedicínsky výskum zahŕňa každú výskumnú činnost' v oblasti biológie, medicíny, farmácie, ošetrovatel'stva, pôrodnej asistencie a psychológie, ktorá môže ovplyvnit' fyzické alebo psychické zdravie človeka, ktorý sa zúčastňuje na tomto výskume. Biomedicínsky výskum zahŕňa lekárske štúdie a štúdie správania týkajúce sa zdravia l'udí. Je to druh činnosti vyvinutej s ciel'om vytvárat' alebo rozvíjat' zovšeobecnitel'né vedomosti pozostávajúce $\mathrm{z}$ teórií, zásad alebo vzt'ahov alebo zhromažd'ovania informácií, na ktorých sú založené, ktoré možno potvrdit' prijatými vedeckými metódami pozorovania.

Biomedicínsky výskum sa najčastejšie definuje ako široká oblast' výskumu, ktorému sa priamo alebo nepriamo podrobujú (ktorého sa zúčastňujú) l'udské osoby. Všíma si l'udský organizmus v zdraví a v chorobe a študuje široké spektrum faktorov, ktoré môžu vplývat' na zdravie jednotlivca, spoločenstiev a celej spoločnosti, ako aj spôsob, akým možno tieto činitele využit’ na upevnenie a prinavrátenie zdravia, predchádzanie chorobám a invalidite, záchranu a predíženie l'udského života, prípadne na zlepšenie jeho kvality v zdraví aj v chorobe. Zahíňa aj výskum liečiv, zdravotných pomôcok, medicínskych prístrojov, medicínskeho využitia ionizujúceho žiarenia a zobrazovacích metód, chirurgických výkonov, údajov v zdravotnej dokumentácii, biologického materiálu l'udského pôvodu, ako aj epidemiologické, sociologické a psychologické výskumy. V súvislosti a paralelne s etickou problematikou biomedicínskeho výskumu sa venuje zvýšená pozornost' aj etickým otázkam výskumu na zvieratách. Biomedicínsky výskum sa neobmedzuje na sféru medicíny ale má širší spoločenský rozmer.

Výskum môže spočívat' nie len na fyziologických, biochemických pokusoch, ale i vo vytváraní záznamov alebo vychádzat' z už existujúcich údajov, ktoré obsahujú medicínske informácie o jednotlivcoch, ktorí môžu alebo nemusia byt' identifikovaní zo záznamov alebo informácií. Biomedicínsky výskum na l’udských organizmoch by sa mal odlišovat' od lekárskej praxe, verejného zdravia alebo iných foriem zdravotnej starostlivosti, ktoré sú navrhnuté tak, aby priamo prispievali k zdraviu jednotlivcov alebo spoločenstiev. Niekedy pacienti môžu byt' pomýlení, ak sa lekársky výskum a prax vykonávajú súčasne; ak je napríklad výskum zameraný na získanie nových informácií o účinnosti lieku alebo inej terapeutickej, preventívnej alebo diagnostickej metódy. Ústava SR garantuje slobodu vedeckého bádania (čl. 43 ods. 1), ktorá však hlavne v prípade medicínskeho experimentu na človeku nemôže byt' neobmedzená. ${ }^{1}$ Musí tu fungovat' rovnovážny, vyvážený pomer medzi slobodou vedeckého bádania výskumníka a ochranou súkromia účastníka výskumu, ktorá zahŕňa právo nebyt' podrobený pokusu bez svojho súhlasu a v prípade účasti byt' o jeho výsledkoch

1 HUMENÍK, I. -SZANISZLÓ, I. M. Biomedicinsky výskum- právne, eticky, filozoficky. Žilina: Eurokódex, 2012, s. 180. 
informovaný. Bioetika sa riadi základnými princípmi, ktorými sú Princíp autonómie a informovaného súhlasu; Princíp zákonnosti; Princíp prínosu a benefície.

\section{Stručný pohl’ad do histórie}

Pôvod výskumu experimentálnou metódou v biológii sa datuje do Alexandrie a Atén v 3. a 4. storočí pred naším letopočtom. Induktívna metóda sa zaviedla v medicíne na prelome 16. a 17. storočia Franciscom Baconom a Galileom Galilei, čo položilo základ experimentálnych vied. 20. storočie prináša inkorporovanie terminológie, ktorá pomohla precizovat' výskum, ako napr. v roku 1931, ked' sa prvýkrát použil pojem klinický pokus a v roku 1938 pojem placebo. Metodológia farmakologického výskumu dozrela vd'aka pôsobeniu Francoisa Magendieho i Clauda Bernarda (1865 vychádza jeho dielo Úvod do štúdia experimentálnej medicíny). Práve Claud Bernard je autorom postulátu ,nikdy na človeku nevykonávat' experiment, ktorý by mu mohol byt' v akomkolvek rozsahu škodlivý, aj ked' výsledok by mohol byt' vel'mi výhodný pre vedu a pre zdravie ostatných. " ${ }^{2}$ I ked” následné obdobie prináša i zneužitie výskumu počas trvania Nemeckej tretej ríše. Dvoma základnými piliermi výskumu na človeku sú Norimberský kódex 1947, ktorý po prvýkrát zaviedol povinnost' informovaného súhlasu, a Helsinská deklarácia Svetovej zdravotníckej organizácie z roku $1964{ }^{3}$

História prináša i mnoho jasných prípadov porušenia etiky výskumu, príkladom je experiment na čiernom syfilise a iné zneužitia medicínskeho experimentu (Tuskegee Valley, Alabama 1932: americkí lekári robili výskum v priebehu ochorenia bez poskytnutia pomoci na 400 černochoch, ktorí verili, že sa im poskytuje bezplatná starostlivost'; projekt Aversion v Juhoafrickej republike znamenal násilné preorientácie a operácie homosexuálov 1971 - 1989). Dodnes je tu mnoho krajín sveta, predovšetkým rozvojových, kde sa realizuje výskum v rozšírenej miere rozvinutými krajinami využívajúc ich obyvatel'stvo na základe finančných okolností a slabej legislatívnej úpravy.

Biomedicínsky výskumu je dnes upravený aj v medzinárodnom meradle samotným Dohovorom o ochrane l'udských práv a dôstojnosti človeka v súvislosti s aplikáciou biológie a medicíny (čl. 29), ktorý SR prebrala zákonom č. 40/2000 Z. z., a právna úprava tu z neho vychádza. Dňa 25. 1. 2005 v Štrasburgu bol prijatý Dodatkový protokol $\mathrm{k}$ Dohovoru o l’udských právach a biomedicíne týkajúci sa biomedicínskeho výskumu (d’alej tiež len ako „Protokol“), ktorý pre Slovenskú republiku nadobudol platnost' 1. 9. 2007. Zákon rešpektujúc terminológiu v týchto medzinárodných prameňoch nahradil pôvodný pojem medicínsky experiment, ktorý staršia právna úprava definovala ako „overovanie nových medicínskych poznatkov.“

\section{Zákonná úprava v Slovenskej republike}

Zákonná úprava ZoZS rešpektuje ustanovenia Dohovoru a je doplnená smernicou Ministerstva zdravotníctva SSR č. 6/1985 Vestníka MZ SSR o postupe pri overovaní

2 BERNARD, C. An Introduction to the Study of Experimental Medicine. New York: Macmillan, 1927, s. 101.

3 VEGA, JMa . - VEGA, J.-MARTINEZ, P. Experimentación humana en Europa: legislación y aspectos bioéticos. Valladolid: Secretariado de Publicaciones de la Universidad, 1997. 
nových medicínskych poznatkov a metód. ${ }^{4}$ Uvedená smernica č. 6/1985 za medicínsky experiment nepovažuje „drobné modifikácie“, príp. „nové čiastkové poznatky, ktoré prispievajú ku zdokonaleniu už verifikovanej hypotézy“ ani „lekárske výkony $\mathrm{v}$ konkrétnych prípadoch u osôb bezprostredne ohrozených na živote za predpokladu, že od výkonu možno očakávat' zlepšenie zdravotného stavu“. Pri experimente sa predpokladá možnost' verifikácie jeho opakovaním a jeho všeobecná použitelnost' na základe poznatkov ním dosiahnutých. Medicínsky experiment v právnom zmysle je treba odlíšit' aj od aplikácie tzv. trial and error metódy v liečbe pacienta spočívajúcej $\mathrm{v}$ tom, že ak nie je úspešná jedna (štandardná) metóda liečby určitej choroby u konkrétneho pacienta, lekár aplikuje inú známu a používanú metódu, o ktorej sa môže so zretel'om k všetkým okolnostiam domnievat', že by v konkrétnom prípade mohla byt' úspešná bez toho, že by hrozilo zhoršenie zdravotného stavu pacienta.

Výskum schval'uje poskytovatel' ústavnej zdravotnej starostlivosti alebo samosprávny kraj. ZoZS vychádza z existencie medicínskeho experimentu so zdravotnou indikáciou (tzv. klinický pokus) a medicínskeho experimentu bez zdravotnej indikácie (tzv. bádatel'ský pokus), ktorý sa môže vykonat' len vtedy, ak riziko alebo zát’až spojené $\mathrm{s}$ účastou $\mathrm{v}$ tomto výskume sú pre účastníka výskumu prijatel'né. Na realizáciu výskumu bez zdravotnej indikácie sú kladené prísnejšie podmienky (ked’že minimálny prínos pre účastníka môže vyvažovat' len minimálne riziko vyplývajúce z účasti). Reflektuje to i odsek 10, ktorý vymedzuje v negatívnom zmysle okruh subjektov, ktoré nemôžu byt' účastníkmi výskumu bez zdravotnej indikácie. Otázka výskumu na živých l'udských zárodkoch a plodoch súvisí s ochranou l’udského života už pred počatím. Právna úprava tu vychádza zase zo samotného Dohovoru, ktorý zakazuje i vytváranie l’udských embryí na výskumné účely (čl.18).

\section{Informovaný súhlas pri výkone medicínskeho experimentu}

Sémanticky sa „tradičný“ informovaný súhlas, typický pre právny jazyk použitel'ný na lekárske činnosti, jednoznačne vzt’ahuje na „chorú osobu“, takže nemôže byt' relevantný pre zdravých dobrovol'níkov, ktorí sa môžu zúčastňovat' na výskume. Je

4 Ochrana človeka pred nezákonným biomedicínskym výskumom je zakotvená v ustanovení § 161 Trestného zákona. Upravuje celkom tri základné skutkové podstaty, a síce vykonávanie overovania nových medicínskych poznatkov bez povolenia napriek tomu, že je ním bezprostredne ohrozený život alebo ohrozené zdravie človeka, ak nejde o nevyhnutné výkony spôsobilé zachránit’ jeho bezprostredne ohrozený život. Rovnako vykonávanie overovania nových medicínskych poznatkov bez povolenia, bez zdravotnej indikácie a bez súhlasu osoby, ktorej sa týka, alebo vykonávanie na osobách, na ktorých je overovanie bez zdravotnej indikácie zakázané, alebo vykonávanie na l’udskom plode alebo zárodku, alebo vykonávanie $\mathrm{v}$ rozpore $\mathrm{s}$ inými zákonnými podmienkami overovania bez zdravotnej indikácie. Taktiež vykonávanie akéhokol'vek zásahu s ciel’om vytvorit' l'udskú bytost' v ktoromkol'vek štádiu jej vývinu geneticky identickú s inou l'udskou bytost'ou, či už živou, alebo mítvou.

Podl'a zákona 362/2011 Z. z. o liekoch a zdravotníckych pomôckach musí byt' pred začatím každého klinického skúšania uzavretá poistná zmluva zodpovednosti za škodu pre prípad, že by v súvislosti s klinickým skúšaním došlo k poškodeniu zdravia alebo úmrtiu účastníka. Pri realizácii biologického výskumu sú klúčové podmienky dohodnuté medzi riešitel'om a d'alšími spolupracujúcimi subjektmi. 
potrebné zdôraznit', že formát informovaného súhlasu, ktorý sa považuje za právny zdroj na ochranu pacientov a účastníkov výskumu (a aj samotných výskumníkov), pochádza z lekárskej oblasti, ale má tu iste dva významy - právny a etický.

Informovaný súhlas je proces, nielen formát, ktorý spočíva $\mathrm{v}$ jasnom prejave kompetentnej osoby (ktorej fyzická, duševná a morálna spôsobilost' jej umožňuje prijat' rozhodnutie) zúčastnit' sa na biomedicínskom výskume. Samozrejme, za takých podmienok, aby mohla poznat' riziká, prínosy, následky alebo problémy, ktoré môžu vzniknút' počas vývoja výskumu, na ktorom sa zúčastňuje. Po formalizácii súhlasu tento proces pokračuje v priebehu výskumu, pretože ak sa pri vypracovaní takejto štúdie zmení akýkol'vek aspekt, bud' metodologický, alebo plánovanie, výskumný pracovník bude musiet' túto skutočnost' oznámit' účastníkovi.

Pri biomedicínskom výskume (aj klinickom skúšaní) informovaný súhlas kladie vyššie nároky, musí spíňat špecifické podmienky, ktoré sú prísnejšie ako podmienky informovaného súhlasu poskytovaného pri štandardnej zdravotnej starostlivosti. Okrem Zákona o zdravotnej starostlivosti je právna úprava obsiahnutá i v zákone č. 362/2011 Z. z. o liekoch a zdravotníckych pomôckach (ZoL). Informovaný súhlas sa musí po formálnej stránke presne evidovat' $v$ dokumentácii skúšania, ktorú posudzuje etická komisia. Teda nestačí len samotný súhlas, hoci je podmienkou sine qua non, ale vyžaduje sa splnenie predpokladov etických a medicínskych. V praxi väčšina informovaných súhlasov v oblasti výskumu, hlavne pri poučení, používa schémy, nákresy, rámček zdôraznenia, rôzne typy písma atd'. Má nadbytočné informácie s nepotrebnými faktami v niektorých častiach a jasné nedostatky informácií v iných. Sú často klamlivé a nejasné. Často prijímajú formu skôr úradného rozhodnutia, čo osoby odrádza a mätie. V prípade medicínskeho experimentu musí mat' písomnú formu poučenie i súhlas pacienta. Ak pacient odmieta poučenie, nemôže sa výskumu zúčastnit'.

ZoZS presne nedefinuje osobu, ktorá má poskytnút' poučenie o detailoch a priebehu výskumu. Malo by íst' o osobu skúšajúceho, ktorý má povinnost' byt' oboznámený $\mathrm{s}$ dokumentmi skúmania a má najlepšie informácie. $V$ rámci klinického skúšania liekov Zákon o liekoch explicitne túto povinnost' ukladá osobe skúšajúceho ( $\$ 44$ písm. b) ZoL). Poučenie má byt' poskytnuté spôsobom v súlade $\mathrm{s} \S 6$ ods. 2 ZoZS a musí mat' vždy písomnú formu, musí byt' datovaný a podpísaný budúcim účastníkom. $\mathrm{V}$ praxi sa odporúča, aby bol na formulári informovaného súhlasu uvedený aj čas jeho udelenia.

Väčším problémom v praxi je získanie súhlasu od osoby nespôsobilej dat' informovaný súhlas, teda maloletého alebo osoby so súdne obmedzenou spôsobilost'ou na právne úkony. To sú faktory, za ktorých osoba nevie reálne posúdit' okolnosti svojej účasti na medicínskom experimente. Za osobu nespôsobilú na udelenie informovaného súhlasu tento súhlas poskytuje ustanovený opatrovník alebo jej zákonný zástupca. Slovenská právna úprava v zásade vychádza z Dohovoru o biomedicíne, ktorý bol v Oviede v roku 1997 otvorený na podpis. Rovnako aj jeho dodatkový Protokol upravuje okolnosti, ked' má byt' účastníkom výskumu osoba nespôsobilá udelit’ informovaný súhlas. Protokol stanovuje rovnako ako naša právna úprava, že súhlas za takúto osobu dáva zákonný zástupca. Zároveň však protokol vyžaduje, aby táto osoba nenamietala svoju účast' na experimente. Čo je z nášho pohl'adu dost' problematická formulácia, ked' uvažujeme o osobách absolútne nespôsobilých posúdit' okolnosti a dianie okolo seba. Čo je podnetné, Protokol na rozdiel od našej národnej úpravy ako podmienku platného súhlasu 
udeleného namiesto účastníka výskumu vyžaduje, že účastník v minulosti nevyslovil nesúhlas so svojou účast'ou na výskume (psychické ochorenie).

Ak pokusná osoba pre svoj psychický alebo fyzický stav nie je schopná udelit' informovaný súhlas s výskumom na základe zdravotnej indikácie alebo ak $\mathrm{z}$ dôvodu neodkladnosti nemožno získat' takýto súhlas včas od jej zákonného zástupcu, možno výskum realizovat' len v prípade podmienok taxatívne stanovených zákonom. $Z$ takejto úpravy možno jasne vyvodit', že súhlas osoby je na prvom mieste. Súhlas osoby sa v takomto prípade nahrádza súhlasom jej zákonného zástupcu. $\mathrm{V}$ poradí ako posledná prichádza do úvahy domnienka o udelení súhlasu osoby s výskumom, čo de facto priamo zo zákona umožňuje súhlas predpokladat' dovtedy, kým nie je možné informovat' osobu alebo jej zákonného zástupcu o účasti osoby v stave vyžadujúcom neodkladnú starostlivost' na medicínskom výskume. Čo najskôr, ako je to reálne možné a stav osoby to dovolí, riešitel' si súhlas musí vyžiadat' pre d'alšie pokračovanie vo výskume.

Posúdenie takto poskytnutého súhlasu je diskutabilné. Dá sa uvažovat'o jeho podmienení súhlasom súdu, ked’že v prípade účasti na medicínskom experimente nejde o rozhodovanie bežných záležitostí osoby, ale o vec, ktorá prekračuje tento rámec. Podobný prípad môže nastat', ak má byt' účastníkom výskumu maloletý, pričom jeden $\mathrm{z}$ jeho rodičov súhlas udelil, no druhý rodič je proti. $\mathrm{V}$ tomto prípade by mal taktiež na základe návrhu jedného $\mathrm{z}$ rodičov rozhodnút' súd (§ 35 zákona č. 36/2005 Z. z. Zákon o rodine v platnom znení). Pri osobách nespôsobilých dat' súhlas prichádza do úvahy taktiež otázka, či by súhlas, aj ked' ho platne udelil už zákonný zástupca takejto osoby, nemal byt žiadaný aj priamo od takejto osoby. Zákon o zdravotnej starostlivosti v $\S 32$ ods. 1 písm. c) súhlas takejto osoby požaduje. Na túto skutočnost' upozorňuje aj smernica Ministerstva zdravotníctva SSR č. 6/1985 Vestníka MZ SSR o postupe pri overovaní nových medicínskych poznatkov a metód, ked' v $§ 3$ ods. 4 vyžaduje pri indikovaných medicínskych experimentoch pri neplnoletej chorej osobe, ktorá je tak rozumovo a mravne vyspelá, že vie pochopit' a posúdit' povahu experimentu, popri súhlase zákonného zástupcu aj súhlas tejto neplnoletej osoby.

Ustanovenie $\S 27$ ods. 2 ZoZS je pomerne detailné, pokial ide o informácie, ktoré musí účastník mat' $\mathrm{k}$ dispozícií. Ak ide o klinické skúšanie liekov, okrem týchto údajov sa musia poskytnút' ešte d’alšie informácie stanovené $§ 29$ ods. 14 ZoL. Medicínsky experiment je bezpochyby vel'kým zásahom do života a práv účastníka a prináša aj svoje riziká. Právny poriadok však v tomto prípade toleruje aj vysoko riskantné nakladanie s vlastným zdravím na účely spoločensky prospešné. Právny poriadok stanovuje rámec, aby sa možné rizikové faktory zmiernili a obmedzili. Základným pravidlom je, že overovanie nových poznatkov na človeku je možné až vtedy, ked' boli vyčerpané všetky ostatné porovnatel'ne efektívne alternatívy a projekt spĺn̆a kritériá vedeckej kvality

Spôsobilost' byt' účastníkom medicínskeho experimentu sa líši z hl'adiska toho, či ide o medicínsky experiment so zdravotnou indikáciou alebo, naopak, bez zdravotnej indikácie. Hovoríme teda o terapeutickom alebo neterapeutickom výskume. Hoci v praxi je pomerne zložité dat' tu striktne deliacu čiaru, napríklad pri výskume chorých na HIV/AIDS alebo pri život ohrozujúcich chorobách.

V prvom prípade (zdravotná indikácia) môže byt' účastníkom medicínskeho experimentu na základe svojho písomného informovaného súhlasu každá osoba. Ak ide 
o osobu nespôsobilú udelit' súhlas (neplnoletú, s obmedzenou spôsobilost'ou), je podmienkou, aby tento súhlas udelil jej zákonný zástupca, prípadne opatrovník. Osobitne v prípade indikovaného medicínskeho experimentu na tehotnej žene, dojčiacej žene, prípadne osobe v stave vyžadujúcom si neodkladnú zdravotnú starostlivost' zákon vyžaduje, aby boli splnené ešte prísnejšie kritériá na povolenie prípustnosti účasti týchto osôb na výskume, ako je to pri ostatných osobách, medzi ktoré patrí predovšetkým skutočnost', že výskum nie je možné vykonat' na osobách, ktoré nesplńajú žiadané špecifikum (napr. tehotenstvo, dojčenie) a výsledky výskumu sú schopné významným spôsobom pomôct' práve takýmto osobám.

Na druhej strane odlišujeme medicínsky výskum bez zdravotnej indikácie. Zákon o zdravotnej starostlivosti priamo $\mathrm{v} \S 26$ ods. 10 zakazuje, aby sa vykonal na:

- živom l'udskom plode alebo zárodku,

- osobe vo väzbe a vo výkone trestu odňatia slobody,

- vojakovi základnej služby, náhradnej služby a prípravnej služby a osobe vykonávajúcej civilnú službu,

- osobe v ústavnej starostlivosti podla $\S 6$ ods. 9 písm. c) a v ambulantnej starostlivosti podla písm. d) zákona o zdravotnej starostlivosti (osoba, ktorá má infekčnú chorobu a osoba s príznakmi duševnej choroby, ktorá ohrozuje seba, prípadne svoje okolie s predpokladom vážneho zhoršenia jej zdravia),

- cudzincovi

Pokial' ide o väzňov, vojakov alebo cudzincov, je možné uvažovat' o možnom zneužití vzhl'adom na špecifický režim týchto osôb, ktorý nedáva záruku úplnej dobrovol'nosti a slobodného informovaného súhlasu. Účast' väzňov v biomedicínskom výskume je povolená vo vel'mi malom počte krajín a ide o kontroverznú prax. Tí, ktorí obhajujú umožnenie účasti väzňov na výskume, tvrdia, že sú obzvlášt' vhodnou skupinou $\mathrm{v}$ tom zmysle, že žijú $\mathrm{v}$ jednotnom fyzickom a psychickom prostredí; tí, ktorí nesúhlasia, tvrdia, že súhlas l'udí vo väzení nemôže byt' platný, pretože je ovplyvnený nádejou na odmenu alebo iné očakávania, ako napríklad podmienená sloboda $\mathrm{v}$ krátkodobom horizonte.

Vo veci spôsobilosti byt' účastníkom medicínskeho experimentu Protokol k Dohovoru z Ovieda vykazuje rovnakú právnu úpravu ako zákon o zdravotnej starostlivosti. Protokol v čl. 20 dokonca umožňuje, aby zmluvné štáty vo svojej vnútroštátnej úprave umožnili vykonávanie lekárskych experimentov aj na osobách zbavených slobody v prípade, ak:

- výskum porovnatel'nej účinnosti nemožno uskutočnit' bez účasti osôb zbavených slobody,

- ciel’om výskumu je prispiet' ku konečnému dosiahnutiu výsledkov, ktoré môžu priniest' prospech osobám zbaveným slobody,

- výskum je spojený iba s minimálnym rizikom a minimálnou zát’ažou.

Formát informovaného súhlasu bude vždy chránit’ práva skúmaných. Nesmieme zabúdat', že tento dokument je len písomnou formalizáciou, nemožno ho vnímat' len ako dokument, ale ako proces, v ktorom budú splnené záväzky a zodpovednosti, ktoré eticky dohodli dvaja morálni agenti (výskumník a účastník).

Podla definície Rady pre medzinárodné organizácie lekárskych vied (CIOMS) v nadväznosti na Helsinskú deklaráciu je základom procesu informovaného súhlasu 
ochrana slobody vol'by jednotlivca a rešpektovanie jeho autonómie a ako dodatočná záruka musí byt' doplnená nezávislým etickým hodnotením výskumných návrhov. Vyššie uvedené je stále viac a viac zdôrazňované najmä u l’udí, ktorí majú t’ažkosti s poskytnutím súhlasu vrátane malých detí, dospelých s vážnymi duševnými poruchami alebo poruchami správania a l’udí, ktorí nie sú oboznámení s koncepciami a technológiami používanými v projektoch. CIOMS odporúča prostredníctvom svojich etických usmernení nikdy nezačat' výskum u l'udí bez získania informovaného súhlasu každého subjektu, a pokial' tu nie je výslovný súhlas, etickej komisie. Navrhuje tiež zohl'adnit' kontext rozvoja kultúrnych skupín iných ako výskumníkovej, ich tradície v oblasti komunikácie a rozhodovania a rešpektovania týchto postupov. Objasňuje, že oprávnenie radou starších alebo vedúcich predstavitel'ov etnických skupín alebo podobných orgánov nemôže $\mathrm{v}$ žiadnom prípade nahradit' povolenie a individuálny súhlas, čo má význam pri zneužití takýchto skupín na výskum.

Informovaný súhlas môže byt' v niektorých typoch štúdií vynechaný, ak to neohrozuje ciele výskumu, najmä v sociálno-psychologickom výskume, takže účastník neupravuje svoje správanie. Niektoré z výskumov sú: vyšetrenia anonymných vzoriek, štúdie založené na zdravotných záznamoch, kde sa zachováva anonymita; vyšetrovania vykonávané $\mathrm{v}$ rámci riadenia neočakávaných alebo neplánovaných núdzových situácií, terapeutické vyšetrenia s potenciálnym prínosom pre subjekt bez toho, aby tento subjekt mohol poskytnút' svoj súhlas; psychologický alebo sociálny výskum, pri ktorom sa usiluje o to, aby správanie subjektu nebolo poškodené poznávaním ciel'a štúdie, pretože by to mohlo mat' rozhodujúci vplyv na skúmanie výsledkov liečby a zváženie protokolov, v ktorých sa pacienti skúmajú v závislosti od zdravotnej starostlivosti (pohotovostná, intenzívna starostlivost', terminálni pacienti, narušená komunikačná kapacita, bezvedomie).

Dnes, v čase rozvoja informačných technológii, sa už uvažuje o forme tzv. dynamického súhlasu (DC dynamic consent alebo online consent). V dobe, ked' sa informácie zdielajú digitálne na globálnej úrovni, mechanizmy klasického informovaného súhlasu zostávajú statické, v papierovej podobe a organizované okolo vnútroštátnych hraníc a právnych rámcov. Preto bol navrhnutý projekt DC biobánk. Kde existuje viac výskumných pracovníkov a výskumných projektov, je t’ažké získat' informovaný súhlas na všetky budúce výskumné použitia v čase náboru. Základom DC je personalizované digitálne komunikačné rozhranie, ktoré spája výskumníkov a účastníkov a stavia účastníkov do centra rozhodovania. V celej Európe existuje viacero príkladov, v ktorých sa dynamický súhlas využíva vo výskumných projektoch (RUDY Study vo VB, CHRIS Južné Tirolsko). Bol zahrnutý i v The World Medical Association WMA Declaration of Taipei on Ethical Considerations regarding Health Databases and Biobanks, 2016. ${ }^{5}$ Zaviest' a prevádzkovat' takýto systém je však finančne náročné. Tiež je tu problém so získaním dostatočne rozmanitých vzoriek účastníkov a preštudovanie informácií je tu náročnejšie ako priamy kontakt s lekárom.

Testovanie liekov na tehotných ženách sa dlhodobo považuje za eticky sporné. Z lekárskeho hl'adiska často t'ažko predpokladat', či je užívanie daných liekov bezpečné

5 WMA - The World Medical Association - WMA Declaration of Taipei on Ethical Considerations regarding Health Databases and Biobanks, Retrieved 21st March 2017, https:/www.wma.net/policiespost/wma-declaration-of-taipei-on-ethical-considerations-regarding-health-databases-and-biobanks/ 
pre tehotné ženy. Preto, prirodzene, dlhodobo sa pristupuje vel'mi opatrne k povoleniu tehotným ženám zúčastňovat' sa na klinických štúdiách. Na druhej strane je logické, že neliečené ochorenie u matky je rovnako nebezpečné aj pre plod. A v situácii, ked' je žena tehotná a trpí vážnym ochorením, je nútená sama skúšat' a podstupovat' riziko bez lekárskej istoty vplyvu postupu na ňu i dieta. Preto bioetici a výskumníci argumentujú, že práve vylúčit tehotné ženy z výskumu je nebezpečné. A na túto potrebu nadväzuje právna úprava, ked' nevylučuje klinický výskum u tehotnej ženy, pokial' je tu benefit pre tehotné ženy a počaté i narodené deti. Požaduje sa, aby riziko pre ženu bolo čo najmenšie. $Z$ medicínskeho hl'adiska sa vylučuje výskum súvisiaci s lekárskym ožiarením, čo by u tehotnej ženy spôsobilo poškodenie plodu. Obmedzenie pri lekárskom ožiarení s použitím rádioaktívnych látok platí pre dojčiace ženy (v mnohých prípadoch pri podaní takéhoto lieku sa žena ani nemôže priblížit' $k$ diet’at'u, lebo vykazuje dočasne žiarenie, takže ani dojčenie nie je možné).

Ak sa už tehotná či dojčiaca žena zúčastňuje výskumu, musia byt' splnené prísnejšie kritériá. Zákon jasne nerieši, či sú potrebné aj nejaké špeciálne podmienky a nároky na informovaný súhlas $v$ tomto prípade, možno implicitne vyvodit', že sa spravuje úpravou všeobecného súhlasu osôb pri medicínskom výskume v zmysle $\S$ 27 ods. 1 ZoZS. Právna úprava nechráni len samotnú ženu, ale poskytuje ju i počatému alebo nenarodenému diet'at'u. Výskum s tehotnými ženami sa môže realizovat' a môže sa robit' eticky. Dnes ide skôr akoby o zhromažd’ovanie údajov - príležitostne, hoci systematicky sa zbierajú údaje o tehotných ženách, ktoré už uživajú lieky. Otázka nestojí, či môže výskum a klinické skúšanie na tehotných ženách prebiehat', ale ako. Dôležitým krokom vpred by bolo požadovat' pri štúdiách, ktoré vylučujú tehotné ženy, aby riešitelia a etické komisie zdôvodnili svoje rozhodnutie. Niektoré medzinárodné lekárske organizácie vo svojich dokumentoch stanovujú i vylúčenie žien, ktoré by mohli otehotniet'. Je to odôvodnené rizikom, že konkrétny liek alebo vakcína je mutagénna. (Vyhlásenia a medzinárodné etické smernice pre výskum a biomedicínske experimentovanie na l’udských bytostiach, prijaté CIOM v r. 1982 v poslednej verzii z r. 2016). ${ }^{6}$

Eliminácia možných nepriaznivých vplyvov výskumu na účastníka je zabezpečená aj možnost'ou odvolat' svoj súhlas s účast'ou na experimente. Rozhodnutie odvolat' svoj súhlas je účastník oprávnený vyjadrit' kedykol'vek bez povinnosti odôvodnenia svojho rozhodnutia. Pri osobách nespôsobilých na vyjadrenie kvalifikovaného súhlasu, ktoré ale vzhl'adom na svoj vek či ochorenie súhlasili s participáciou na klinickom pokuse, to platí rovnako, a to aj v prípade, že by s d’alšou účast'ou tejto osoby súhlasil jej zákonný zástupca či opatrovník. Riešitel' má akceptovat' prejav nesúhlasu tejto osoby s d’alším pokračovaním svojej účasti na experimente.

Medzi kritické prvky, ktoré sa majú monitorovat' vo všetkých klinických experimentoch, patrí dodržiavanie postupov informovaného súhlasu, požiadavky na začlenenie a vylúčenie osoby, primerané a včasné monitorovanie bezpečnosti, dodržiavanie vyšetrení a následné opatrenia podl’a protokolu a preskúmanie regulačných dokumentov. Metódy môžu zahŕňat' posúdenie rizika s ciel'om určit' optimálne spô-

6 V júli 2018 svet zasiahol prípad úmrtia 11 novorodencov v Holandsku, ktorí zomreli na plúcne zlyhanie potom, ako sa ich matky počas tehotenstva zúčastnili na výskume súvisiacom $\mathrm{s}$ problémami s placentou. 
soby monitorovania, berúc do úvahy pravdepodobné zdroje chýb, ich dôsledky pre účastníkov a dostupné zdroje.

\section{Etická komisia v biomedicínskom výskume}

Je prirodzené, že právna regulácia lekárskeho výskumu na l'ud'och nemôže pokrývat' všetky podrobnosti, prax je variabilná v ciel'och, technikách a neustále tu vznikajú nové etické i právne otázky. Dokumenty sa obmedzujú na stanovenie všeobecných zásad a d'alšie je v rukách etických komisií, ktoré schvalujú výskumné protokoly a možné účinky výskumu.

Pri posudzovaní biomedicínskeho výskumu etická komisia predovšetkým zvažuje a hodnotí, či sú dostatočne zabezpečené práva na ochranu osobnosti, rešpektovanie telesnej a psychickej integrity, garantovanie bezpečnosti a oprávnených záujmov účastníkov medicínskeho experimentu. Vyhodnocuje, či v procese výskumu nedôjde k neprípustnému ovplyvňovaniu účastníkov, či riešitel' biomedicínskeho výskumu postupoval zákonne a korektne pri získavaní informovaného súhlasu. Po posúdení predloženej dokumentácie etická komisia vydá písomné stanovisko k etickej prijatel'nosti výskumu s odôvodneným záverom v lehote 90 dní od predloženia. Následne sleduje priebeh výskumu a nie je zriedkavé, že komisia svoje pôvodné stanovisko o etickej prijatel'nosti zmení a reviduje (napr. ak sa prejaví závažný nežiadúci účinok).

Vo väčšine európskych krajín sú pacienti alebo ich zástupcovia zapojení len okrajovo alebo vôbec nie do etického a vedeckého preskúmania klinických skúšok. Vo vnútroštátnych právnych predpisoch väčšiny európskych krajín, ako aj v nariadení EÚ o klinických skúškach (nariadenie EÚ č. 536/2014) zapojenie pacientov do vymedzenia etických podmienok pre klinické skúšky a do preskúmania etickými komisiami nie je jasne definované. V nariadení sa uvádza: „Pri určovaní príslušného orgánu alebo orgánov (t. j. etických komisii) zapojených do posudzovania aplikácii by členské štáty mali zabezpečit’ zapojenie laikov, najmä pacientov alebo organizácii pacientov."

Po ukončení výskumu musia výskumní pracovníci predložit' správu o výsledkoch výskumu etickej komisii, ako to stanovuje Dodatkový protokol Dohovoru z Ovieda o biomedicínskom výskume. Ak sa i výskum ukončí predčasne, predkladá sa správa s uvedením dôvodov predčasného ukončenia. Dodatkový protokol d’alej požaduje, aby výsledky štúdie boli v primeranom čase zverejnené a závery výskumu sa poskytli účastníkom, ktorí si to želajú. Rovnako výskumní pracovníci by mali potvrdit' svoje návrhy uvedené v žiadosti o schválenie výskumu, pokial' ide o publikovanie výsledkov výskumu vo vedeckých časopisoch alebo ich zverejnenie inými spôsobmi. Ako hovorí Príručka pre členov etických komisií, ${ }^{7}$ celkové závery výskumu sa poskytujú v zrozumitel'nej forme každému účastníkovi výskumu, ktorý má o ne záujem. Hoci poskytovanie tejto informácie musí rešpektovat' záujmy tretích strán, ako sú zadávatel' výskumu (research sponsor) alebo aj samotní výskumní pracovníci, nemožno to použit' ako ospravedlnenie nerešpektovania legitímneho práva účastníkov poznat'

7 Príručka pre členov etických komisií, Riadiaci výbor pre bioetiku, English Edition: Guide for Research Ethics Committee Members, Council of Europe, June 2012, dostupné na http://www. bioetika.sk/files/guide-sk.pdf 
výsledok výskumu, ku ktorému svojou účast'ou prispeli.

Je dôležité, aby sa výsledky výskumu zverejnili, a to bez ohl'adu na to, či výskumnú hypotézu potvrdili (pozitívne výsledky), nepotvrdili (negatívne výsledky) alebo takýto záver neumožnili (nepresvedčivé výsledky). Potlačenie zverejnenia výsledkov nielen narušuje výskumné úsilie iných výskumných skupín, ktoré sa o nich nedozvedia, ale môže sa priamo dotknút' aj pacientov, ktorí môžu byt' zbytočne zarad'ovaní do nepotrebného opakovaného výskumu. Navyše, systematická akumulácia a analýza výsledkov výskumu je potrebná na rozvoj d'alšieho výskumu.

Vel'mi zriedkavo sú výsledky jedinej klinickej štúdie natol'ko jednoznačné, že majú bezprostredný vplyv na klinickú prax. Pokrok závisí skôr od vykonávania nového výskumu a interpretácie jeho výsledkov v kontexte systematických prehladov (systematic reviews) všetkých relevantných a spol'ahlivých poznatkov (evidence). Pokial' zostáva čast' týchto poznatkov nepublikovaná, celkový súhrn poznatkov je skreslený, a preto nespol'ahlivý. Pacienti potom môžu d’alej dostávat' liečbu, ktorá je v skutočnosti škodlivá, alebo, naopak, nedostanú liečbu, ktorá by im pomohla. Etická komisia sa preto musí presvedčit', že výskumní pracovníci formulovali pravidlá pre publikovanie výsledkov (publication policy), ktoré vopred dohodli s prípadnými externými zadávatel'mi výskumu (research sponsors), takže nie sú zmluvne viazaní, aby potlačili šŕrenie svojich výsledkov. Primeraný časový posun v publikovaní výsledkov je akceptovatel'ný (napr. z dôvodu, aby sa nenarušilo podanie patentu), ale nesmie sa použit' ako ospravedlnenie na to, aby sa výsledky neposkytli vôbec. Osobitné obavy vo vzt’ahu ku skreslenému (biased) publikovaniu výsledkov výskumu, ktorý sa týkal potenciálnych nových spôsobov liečby, sa týkali najmä možného zatajovania jeho „,nepriaznivých“ výsledkov. Výskumní pracovníci majú vopred registrovat’ projekty biomedicínskeho výskumu vo verejne dostupnom registri. Etická komisia môže podporit' toto úsilie o transparentnost' tým, že podmieni svoje pozitívne stanovisko $\mathrm{k}$ výskumu takouto registráciou. Aj pokial' platná legislatíva $\mathrm{v}$ danom štáte neumožňuje podmienečné schválenie výskumu na takomto základe, Etická komisia má vždy požadovat', aby boli všetky výsledky výskumu zverejnené. Treba vziat' do úvahy potenciálne d'alšie spôsoby využitia výsledkov výskumu. Transparentnost' je obzvlášt' dôležitá, pokial' sa očakáva komerčné využitie výsledkov výskumu. ${ }^{8}$

\section{Ďalšie páva účastníka biomedicínskeho výskumu}

Biomedicínsky výskum zahíňa väššie riziká pre subjekt než pri poskytovaní bežnej zdravotnej starostlivosti. Preto je namieste venovat' zvýšenú pozornost' ochrane zdravia účastníkov výskumu. Ochrana je účastníkom de facto poskytnutá už samotným inštitútom informovaného súhlasu, kontrolou a schval'ovaním projektov výskumu etickými komisiami. ZoZS osobitne precizuje postup pri medicínskom výskume realizovanom na ženách alebo s použitím lekárskeho ožiarenia či placeba. Výskum s účast'ou pacientov je často spojený so zdravotnou starostlivostou, ktorá sa im poskytuje, a nálezy získané počas klinickej starostlivosti môžu byt' dostačujúce na účely vý-

8 GLASA, J. Etické komisie a biomedicinsky výskum, Vybrané inštitucionálne a etické aspekty, Masarykova Univerzita Brno Lékařská fakulta - Ústav lékařské etiky, 2006. https://is.muni. cz/th/udu6q/DrGlasa_-_dizertacia_-_def.pdf 
skumu. Pokial' to tak nie je alebo pokial' takéto výsledky nie sú dostatočné vzhl'adom na kritériá daného výskumného projektu, má sa počítat's potrebnými dodatočnými vyšetreniami, testami, ktoré je potrebné zahrnút' do výskumného protokolu.

V zmysle $\S 29$ ods. 1 ZoZS má zodpovedný riešitel' uplatnit' všetky potrebné opatrenia na zabezpečenie bezpečnosti a zníženie rizika a zátaže účastníkov výskumu a v prípade, ak je ohrozené zdravie alebo bezpečnost' účastníkov pokusu, má táto zodpovedná osoba v zmysle $\S 30$ ods. 3 ZoZS povinnost' okamžite zabezpečit' potrebné opatrenia. Zodpovedná osoba má taktiež povinnost' o nových skutočnostiach, ktoré spôsobujú zvýšenie rizika, bezodkladne informovat' účastníkov klinického experimentu, a ak je to potrebné, vyžiadat' si od nich nový informovaný súhlas. Legislatíva umožňuje riešitel'ovi rozhodnút' sa, či o nový informovaný súhlas účastníka požiada alebo nie. Podl’a nášho názoru by túto povinnost' $\mathrm{v}$ prípadoch neočakávanej zmeny podmienok pokusu mala zodpovedná osoba mat'. V prípade vzniku škody na zdraví by mohla novým informovaným súhlasom preukázat', že so zvýšeným rizikom bol účastník pokusu uzrozumený a súhlasil so svojou účast'ou na pokuse aj za nových podmienok.

Účastníkovi medicínskeho experimentu musí byt' počas celej realizácie výskumu poskytnutá čo možno najvyššia miera ochrany, pričom riziká vyplývajúce z výskumu musia byt' čo najviac minimalizované a eliminované. Uvedený princíp sa realizuje napr. cez povinnost' stáleho lekárskeho dohl'adu či skúmania dôvodnosti pokračovania vo výskume. Ako zákon, tak aj Protokol k Dohovoru zhodne stanovujú dôležitú zásadu, výskum „,nesmie zdržovat' alebo bránit' preventívnym, diagnostickým alebo liečebným lekárskym postupom, ktoré účastníci potrebujú." Riešitelia výskumu majú informačnú povinnost' vo vzt’ahu k schval'ovatel'ovi a etickej komisii. Tá sa týka priebehu a prípadných zmien vo výskume alebo jeho predčasnom ukončení. Rovnako vo vzt’ahu k účastníkom výskumu je tu povinnost' informovat' o všetkých zmenách $\mathrm{v}$ procese výskumu a je potrebné okamžite zabezpečit' opatrenia na ich ochranu.

Z hladiska právnej zodpovednosti poukazujeme na Občiansky zákonník (zákon č. 40/1964 Zb.).Ustanoveniami $\S 431, \S 432 \mathrm{OZ}$ sa spravuje zodpovednost' za škodu spôsobenú zvlášt' nebezpečnou prevádzkou, za ktorú je považovaný i medicínsky experiment - nie však už aplikácia medicínskych výkonov lege artis). V tomto prípade ide o všeobecnú objektívnu zodpovednost', ktorej sa takáto experimentujúca inštitúcia nemôže zbavit' nijakými liberačnými dôvodmi. Na vznik objektívnej zodpovednosti je potrebné preukázat' súvislost' medzi experimentom a spôsobenou škodou. Objektívnou zodpovednostou je teda osoba chránená pri medicínskom experimente a pri škode, ktorá mala pôvod $\mathrm{v}$ rizikách použitia diagnostického alebo terapeutického prístroja, veci. Osoba však nie je chránená v prípade škody vyplývajúcej z rizika použitia napr. diagnostickej, terapeutickej, liečebnej alebo inej medicínskej metódy.

Ako sme uviedli, účastník má právo na výsledky a závery biomedicínskeho výskumu. Sprístupnenie informácií možno vnímat'v troch smeroch, jednak je tu písomné informovanie etickej komisie a schval'ovatel’a, jednak vo vzt’ahu k účastníkom výskumu a tiež verejnosti. V posledných dvoch prípadoch zákon nepredpisuje špeciálnu formu, treba dodržiavat' všeobecné zásady nakladania s informáciami o pacientovi.

Účastník má právo na to, aby mu riešitel' oznámil informácie o jeho zdravotnom stave, ktoré získal v priebehu participácie účastníka na výskume. V otázke práv účastníka byt' informovaným o výsledkoch výskumu je Protokol k Dohovoru z Ovieda rov- 
nako ako Zákon o zdravotnej starostlivosti jednoznačný a v čl. 26, ako aj v čl. 28 ods. 2 zaväzuje riešitel’a, aby tieto informácie účastníkovi výskumu sprístupnil. Výsledky výskumu sa účastníkovi zverejnia na základe jeho žiadosti.

Informáciu týkajúcu sa ich zdravia môže byt' súčastou výsledkov výskumu alebo sa môže získat' neočakávane. Výskumní pracovníci majú zhodnotit' význam tejto informácie pre súčasné alebo budúce zdravie alebo kvalitu života účastníkov výskumu - a môžu túto skutočnost' konzultovat's etickou komisiou. Ked' sa má táto informácia poskytnút', musí sa to diat' v rámci zdravotnej starostlivosti alebo poradenstva, aby klinickí pracovníci mohli účastníkom výskumu vysvetlit' povahu a význam daných výsledkov spôsobom, ktorý umožňuje l'ahké pochopenie, a podobne aj prediskutovat' možnosti, ktoré sú $\mathrm{k}$ dispozícii vzhl'adom na prevenciu, liečbu alebo iný postup. Je dôležité pamätat' na to, že výsledky výskumu s klinickým významom je zvyčajne potrebné d’alej overovat'. Rozhovory s účastníkmi výskumu musia byt' dôverné a právo účastníka odmietnut' danú informáciu sa musí vždy rešpektovat'.

\section{Záver}

V súčasnosti sme svedkami obnovenia dôležitosti práv pacientov ako základnej osi vzt'ahov klinickej starostlivosti, ako aj potreby nových spôsobov ich ochrany pred následkami rozvoja informatiky, genetického pokroku a globalizácie klinického výskumu. Záujem o bioetiku prejavujú všetky medzinárodné organizácie s právomocou v tejto oblasti. Zákonná definícia biomedicínskeho výskumu je naozaj pomerne široká. Prvotným účelom a charakteristickou črtou biomedicínskeho výskumu je zvyšovanie kvality zdravia pri súčasnej redukcii počtu ochorení resp. ochorení významne ovplyvňujúcich kvalitu života.

Slovenská právna úprava biovýskumu je obsiahnutá v rôznych právnych normách, čo môže byt' problematické, ale je v súlade s Dohovorom o ochrane l'udských práv a dôstojnosti človeka $\mathrm{v}$ súvislosti s aplikáciou biológie a medicíny a jeho dodatkového protokolu.

Vzhl'adom na dôležitost' hodnôt, ktoré sú vložené do lekárskeho výskumu, obvyklý informovaný súhlas typický pre každodenné lekárske postupy a starostlivost' sa nedá aplikovat' na experimentálne zásahy. Možno konštatovat', že práva účastníkov výskumu sú pomerne podrobne upravené, problematickým bodom, ako i pri informovanom súhlase všeobecne je jeho poskytnutie osobou, ktorá nemá plnú spôsobilost' na právne úkony a je tu inkorporácia rozhodovania jej zástupcu. Prikláňame sa $\mathrm{k}$ názoru, že $\mathrm{v}$ tomto prípade by tento súhlas mal byt’ podmienený súhlasom súdu. Je správne, že zákon poskytuje zvýšenú ochranu špeciálnym skupinám osôb, ako sú tehotné ženy.

Výskum sa často realizuje na medzinárodnej úrovni, vyžaduje sa spracovanie a uchovávanie vel'kého množstva dát. Metódy zapojenia účastníkov neudržali tempo so zmenami výskumných kapacít, a preto sa udomácňujú nové formy informovaného súhlasu v digitálnej forme. Evidentne je to práve oblast' medicíny, ktorá bude do budúcnosti stavat’ pred právnu reguláciu najväčšie výzvy. 


\section{Literatúra:}

- BERNARD, Claude. An Introduction to the Study of Experimental Medicine. New York: Macmillan, 1927, 226 s. dostupné na: https://archive.org/stream/ b21270557/b21270557_djvu.txt

- GLASA, Jozef. Etické komisie a biomedicinsky výskum, Vybrané inštitucionálne a etické aspekty. Brno: Masarykova Univerzita Brno, Lékařská fakulta - Ústav lékařské etiky, 2006, 88s. https://is.muni.cz/th/udu6q/DrGlasa_-_dizertacia_-_ def.pdf

- HUMENÍK, Ivan - SZANISZLÓ, Inocent-Mária. Biomedicinsky výskum právne, eticky, filozoficky. Žilina: Eurokódex, 2012, 336 s.

- KOPECKÁ, Katarína a kol. Zdravotnicka etika. 2. Vyd. Martin: Vydavatel'stvo Osveta, 2008, 119 s.

- RAUDENSKÁ, Jaroslava - JAVURKOVÁ, Alena. Lékařská psychologie ve zdravotnictví. Praha: GRADA, 2011, 304 s.

- $\quad$ RICHMAN, Wee - HENAGHAM, Mark - WINSHIP, Ingrid. (December 2013). Dynamic consent in the digital age of biology: online initiatives and regulatory consideration“. Journal of Primary Health Care. 5 (4): 341. doi:10.1071/ HC13341. Retrieved 16 January 2017.

- SVEJKOVSKÝ, Jaroslav - VOJTEK, Petr - ARNOŠTOVÁ, Lenka Teska a kol. Zdravotnictví a právo. Praha: C. H. Beck, 2016, 488 s.

- S ŠUSTEK, Petr-HOLČAPEK, Tomáš a kol. Zdravotnicke právo. Praha: Wolters Kluwer ČR, 2016, $852 \mathrm{~s}$.

- VEGA GUTIÉRREZ, José Maria - VEGA, Javier - MARTINEZ BAZA, Pelegrín. Experimentación humana en Europa: legislación y aspectos bioéticos. Valladolid: Secretariado de Publicaciones de la Universidad, 1997, 208 s.

- WMA - The World Medical Association - WMA Declaration of Taipei on Ethical Considerations regarding Health Databases and Biobanks, Retrieved 21st March 2017, https://www.wma.net/policies-post/wma-declaration-of-taipei-on-ethicalconsiderations-regarding-health-databases-and-biobanks/

- Príručka pre členov etických komisií, Riadiaci výbor pre bioetiku, English Edition: Guide for Research Ethics Committee Members, Council of Europe, June 2012, dostupné na http://www.bioetika.sk/files/guide-sk.pdf

Summary: The Rights and Obligations of a Biomedical Research Participant With an Emphasis on Informed Consent

The Slovak legislation on biomedical research is contained in various legal norms, what may be impractical, but is in line with the Convention for the Protection of Human Rights and Human Dignity in connection with the application of biology and medicine and its Additional Protocol. Given the importance of the values that are embedded in medical research, the usual informed consent typical of everyday medical procedures and care cannot be applied to experimental interventions. It can be stated that the rights of research participants are regulated in detail, the problematic point, as well as in the case of informed consent in general, is consent of person who does not have full legal capacity and there is the incorporation of the decision of its representative. We are of the opinion that in this case, this consent should have been 
subjected to the consent of the court. Participation methods have not kept pace with changes in research capacities, and therefore new forms of informed consent in digital form are being adopted.

JUDr. Katarína Ševcová, PhD. Právnická fakulta Univerzity Mateja Bela Katedra občianskeho a pracovného práva Komenského 20, 97401 Banská Bystrica Slovenská republika e-mail: katarina.sevcova@umb.sk 